\title{
Innovation in the government-run Continuing Vocational Education and Training programme for unemployed in Catalonia (Spain): Challenges and opportunities
}

\author{
Liviu Catalin Mara iD \\ Universitat Rovira i Virgili (Spain) \\ liviucatalin.mara@urv.cat
}

Received March, 2018

Accepted April, 2018

\begin{abstract}
Purpose: This paper offers relevant insights from the activity of the network of Centres d'Innovació $i$ Formacio Ocupacional (CIFO), analyzing the development of innovation in a continuing education and training (CVET) programme for unemployed, in Catalonia (Spain).

Design/methodology: This is a qualitative study, carried out using the communicative methodology approach and co-constructing knowledge with the heads of the centers. The data was collected through the realization of eight interviews with the heads of seven of the eight CIFO that compose the CIFO network in Catalonia plus the Coordinator of the network, who had been head of the other CIFO, and it consisted in identifying the barriers to innovation and the elements that help to overcome them within different dimensions of this programme, through the exclusionary and transfomative dimensions, specific to the communicative methodology.
\end{abstract}

Findings: Innovation at the CIFO has three main strands where we have identified many opportunities for the CIFO: methodological, pedagogical and technological. The methodological has to do with the actions derived from the ISO 9001 certification, which gives the centres the mission of continuous improvement and satisfying the needs of the people and enterprises in the territories they serve. Pedagogical innovation is related to the detection of the innovation and including it in the curriculum of the centre, organizing experimental training courses, using the project methodology, enhancing entrepreneurship, or introducing digital technologies in the classroom. Technological innovation is related to the use of the latest technologies and equipment in the market.

Social Implications: This study opens new venues for research in the area of VET, CVET and lifelong learning because of its implications in adjusting education and training to the requirements of the labor market and improving students' employability and helping them develop or design their personal projects and professional trajectory. The processes described in this article could be transferred to other contexts and in all types of activities or initiatives in lifelong learning.

Originality/value: This study contributes to fill a gap in the scientific literature, because innovation in the area of continuing vocational and education training and even in lifelong learning is scarce. Another contribution of this article is the focus on innovation, which is one of the main priorities for the EU in the area of Education and Training, and also in the US, because of its contribution to economic growth and competitivity.

Keywords: Innovation, CIFO, CVET, Lifelong learning, Communicative Methodology 
Jel Codes: O3, O31, Q55

\section{Introduction}

The pressing demands for a more educated workforce caused by the global economy in the United States (Kallison, 2017) exist also in the European Union (EU) (Lundvall \& Rasmussen, 2016). At the same time, the literature observes that in the area of Adult Learning and Education there is a trend consisting in favoring educational initiatives related to VET, due to its incidence in economic growth and competitiveness (Boeren \& Holford, 2016), a similar phenomenon also observed in Spain (Lucio-Villegas, 2012). As a response to these phenomena, the EU established four objectives for education and training systems within the lifelong learning perspective, that the Member States (including Catalonia as part of Spain) should implement by 2020 and one of them is 'enhancing creativity and innovation, including entrepreneurship, at all levels of education and training' (European Council, 2009, p. 3). So far, research has mostly focused on the innovation on the VET formal educational systems, in different national or comparative contexts. For a comprehensive review in this field see Toner and Woolley (2016); there are also significant contributions from the European Union (Cedefop, 2015) and in Spain, examples from Basque Country (Porto, Zabala-Iturriagagoitia \& Larrakoetxea, 2017; Albizu, Olazaran, Lavia \& Otero, 2017) or Catalonia (Brunet \& Rodriguez-Soler, 2014).

What the scientific literature calls continuing professional education (CPE), 'where trainings often build on knowledge initially developed through higher education' (Stummann, 2014, p. 323), and the continuing vocational education and training (CVET) for unemployed (also called occupational training) are integrated at the legislative level in one education and training system in Catalonia, although they each have different funding channels. The focus of this study is on the CVET for unemployed, which is a part of the Adult Learning and Education (and implicitly, within the lifelong learning) concerned with the education or training of individuals after they complete their compulsory education or enter the working life (Cedefop, 2014). The government-run CVET programme for unemployed in Catalonia analysed here seeks to increase the employability of the unemployed by offering free training courses in skills demanded in the Catalan labor market. In contrast to CPE, little research has been done on CVET for unemployed, on innovation, or how can innovation be introduced in different education and training systems, especially in the case of CVET which, as in the present case, is not part of the formal educational system, but instead it is developed under the Labor authority of the Catalan Government. Thus, the objective of this article is to contribute to the field of knowledge regarding innovation in the lifelong learning through the study of the CVET government-run programme for unemployed in Catalonia, bearing in mind that our findings can be transferred to other initiatives or activities in lifelong learning.

\section{Literature review}

Lifelong learning is a contested field of research and it is beyond the scope of this article to dwell on the different perspectives and conceptualizations of it. Suffice it to say that the CVET programme for unemployed that we study here is a non-formal education programme, part of the lifelong learning, and that the EU, cofunder of this programme in Catalonia, defines lifelong learning as 'all learning activity undertaken throughout life, with the aim of improving knowledge, skills and competences within a personal, civic, social and/or employment-related perspective' (European Commission, 2001, p. 9). EU is among the most important advocates of innovation, and it does so through its lifelong learning policies, such as the EU 2020 ERASMUS + programme (Ehlen, van der Klink \& Boshuizen, 2016).

CIFO network is part of the Catalan Employment Service, within the Labor, Social Affairs and Families Department. As noted by Mulgan and Albury in 2003, and quoted by Durrani (2007, p. 190), innovation has the potential to improve the overall action of the public sector by improving performance, efficiency and meeting citizens needs:

Innovation should be a core activity of the public sector: it helps public services to improve performance and increase public value; respond to the expectations of citizens and adapt to the needs of users; increase service efficiency and minimise costs. 
Sauer (2011, p. 70) considers that innovation and learning are inseparable: innovation is unthinkable without lifelong learning; innovation and lifelong learning are two sides of the same coin'. Furthermore, this author sees work that conduces to learning as fundamental for the development of the innovative capacity and also to advance to the knowledge society. Moreover, in the context of the knowledge society there is a high demand for new qualifications in emerging or innovative economic sectors (Guimarães, 2012). The new training or new qualifications are related to improving production and innovation, and learning linked to innovation can have an impact in the motivation of individuals to participate in the lifelong learning (Janssens 2002). Sauer (2011, p. 75) also notes that 'traditional continuing education' is involved on an exceptional basis in incremental innovations while it is more involved in establishing instant innovations. Piercy (2010), claims that in order to be innovative, lifelong learning needs the government to support innovation.

Jackson (2010) argues that pedagogic challenges can be used to develop innovations in lifelong learning, if they 'develop new cultures of learning, finding ways not only to recognise the power relations embedded in constructions of knowledge and of learning, but also in finding ways for teachers and learners to resist and reclaim them' (Jackson, 2010, p. 7). Accordingly, the innovative pedagogy for lifelong learning (Jackson, 2010) consists in shifting the learning from a 'human capital model' of lifelong learning to a 'humanistic model' (Regmi, 2015). Nonetheless, Jackson (2010, p. 8) notes that lifelong learning 'at its best' can help individuals achieve, at the same time, the goals contained by the two models. For the EU, an innovative pedagogy consists in placing the individual at the centre of the educational process: 'a shift from "knowledge" to 'competence' and from teaching to learning, placing the learner at the centre' (European Commission, 2001, p. 23), and the use of methodologies such as work-based learning, project-oriented learning or "study circles" (European Commission, 2001). Renta, Van den Bossche, Gijbels and Fandos (2017), note other elements of pedagogical innovations used in vocational education, such as simulations, visit to companies or internships.

As mentioned in the introduction, the fourth objective of the Strategic Framework for European cooperation in education and training ('ET 2020') is related to the promotion of the innovation in all type of education within the lifelong learning. The EU acknowledges innovation as a driver of sustainable economic development and an important factor for economic competitiveness internationally (European Council, 2009). The EU establishes two priority areas for this objective: the acquisition of transversal key competences (digital, learning to learn, entrepreneurship, cultural awareness); and the development and functioning of a knowledge triangle between education, research and innovation, which includes partnerships between enterprises and education and training at all levels in order to address the skills and competences needed in the labor market and foster innovation and entrepreneurship (European Council, 2009). Lastly, the EU recommends the involvement of representatives of civil society and other stakeholders in order to create a climate favourable to creativity and meeting individual well-being, the professional and social needs (European Council, 2009).

One last contribution of the scientific literature regarding lifelong learning builds upon the use of the technology in education and training. Some of these examples are the MOOCs (Steffens, 2015) or distance learning and e-learning (Regmi, 2015). Billon, Lera-Lopez and Marco (2017), consider that the use of the digital technologies has a high potential for innovation. However, Elfert (2015) recalls the concerns manifested in the Faure report, related to the deshumanization and standardization of the individual behavior as a consequence of the technical change and emphasises the role of imagination and creativity in order to preserve human freedom. Finally, political action is called to a continuous update of the education in order to include the new features and developments of society and democracy:

The aim and content of education must be re-created, to allow both for the new features of society and the new features of democracy. For these reasons, the commission stressed the fact that education must be regarded as a domain where political action is of especially decisive importance (Faure et al., 1972, xxvi). 


\section{Communicative Methodology}

Communicative Methodology is well established both at the European Union and international scientific levels. It draws on the contrast between the knowledge, reflections and the interpretations of the people who are involved in the phenomenon that is being studied, with the knowledge, reflections and interpretations of the academic community, in order to enable social change (Gómez, Puigvert \& Flecha, 2011). The product of the egalitarian dialogue between these two types of knowledge is a new scientific knowledge adapted to the specific problems that the individuals are dealing with and it includes proposals to address these problems (Gómez, Puigvert \& Flecha, 2011). In our study of the relationship between CVET and innovation, the use of the communicative methodology is necessary because the huge gaps in the scientific knowledge in this area demands for the co-construction of knowledge with the stakeholders who have experience in this activity. Besides, the data analysis was carried out using the perspective of the communicative methodology, which means identifying the exclusory and the transformative dimensions in the discourse of the participants. With this qualitative study we pretend to analyse the challenges and opportunities to innovate in the CVET in Catalonia, being aware that the proposals identified here can also be applied in other contexts.

\subsection{Data collection}

This study has been carried out in 2016, within the framework of a competitive research project on the VET system (formal education) and innovation. The data was collected through the realization of eight interviews with the heads of seven of the eight CIFO that compose the CIFO network in Catalonia plus the Coordinator of the network, who had been head of the other CIFO (Table 1). Seven of the interviews were audio recorded and notes have been taken from one interview, respecting the request of the interviewee. The fieldwork coincided with a period of transition, because all the CIFO were going through a process of change, including at the leadership level, due to legal modifications started in 2015 in Catalonia. Even the coordinator of the network was in the middle of the power transfer to the new head of one of the CIFO at the moment of the interview, so she could talk both about the CIFO and the network coordination; furthermore, at one of the centres, both the current and the former head of the centre participated at the interview. The interviews were realised following a communicative approach, using dialogue in order to reflect and understand aspects of the present and of the future, and how the person resolves specific situations in the daily life of the centre, in relation to innovation (Gómez, Latorre, Sanchez \& Flecha, 2006).

\begin{tabular}{|c|c|}
\hline Code & Date \\
\hline CF16ACUP01 & February 2016 \\
\hline CF16ACUP02 & February 2016 \\
\hline CF16ACUP03 & March 2016 \\
\hline CF16ACUP04 & March 2016 \\
\hline CF16ACUP05 & April 2016 \\
\hline CF16ACUP06 & April 2016 \\
\hline CF16ACUP07 & April 2016 \\
\hline CF16ACUP08 & April 2016 \\
\hline
\end{tabular}

Table 1. Interviews with the Directors of 7 CIFO and with the Coordinator of the CIFO network, in Catalonia

\subsection{Data analysis}

The guidelines for the interviews that we used were elaborated for the project mentioned above, in base of the literature review on innovation and VET centres. During the first interview these guidelines were adapted to the study of the CIFO, in a collaborative and dialogic approach with the interviewee, and we used the new guidelines for the rest of the interviews. In these new guidelines four categories of analysis emerged, that explain the relationship between CIFO and innovation, as we can see below in the columns; in the rows, the transformative and exclusionary dimensions (Table 2). Autonomy refers to the organizational factors that limit or enhance CIFO capacity to innovate. Pedagogy refers to the elements that limit or enhance CIFO curriculum to innovate. Innovation 
refers to the obstacles and elements of direct innovation introduced or developed by the CIFO. Collaboration refers to obstacles and elements of collaboration between the CIFO and other stakeholders, for innovation.

Thus, we analysed the four categories related to innovation, which resulted from the script used in the interviews, using the exclusionary ('the elements that contribute to the social problem analysed') and transformative ('elements that contribute to overcome the barriers behind the problem explored') dimensions (Pulido, Elboj, Campdepadros \& Cabre, 2014, p. 892), which represent one of the unique contributions of the Communicative Methodology. First, the interviews were transcribed entirely and after that the information was regrouped in base of the four categories. Second, within each category, the information was grouped as an exclusionary or transformative dimension depending if it represented an obstacle or an element that allowed to overcome an obstacle, respectively. Third and last, the information included in the article was selected following several criteria: include the voices of as many centres as possible; relevance to the topic; richness of the information, and diversity of examples. The selection of the information was done one by one, highlighting the text of the transcripts and using numeric codes, following the postulates of the communicative methodology. Thus, the squares with numbers represent the cross between categories and dimensions, and their purpose is to classify the information when we analysed the transcriptions (Gómez, Latorre, Sanchez \& Flecha, 2006, p. 102). For example, when we found an element that enhances innovation in the transcriptions, we highlighted the phrase or paragraph and put it under code " 6 "; thus, code " 6 " contains all the references to elements that enhance innovation at the CIFO.

\begin{tabular}{|l|r|r|r|r|}
\hline Dimension \Category & \multicolumn{1}{|c|}{ Autonomy } & \multicolumn{1}{|c|}{ Pedagogy } & \multicolumn{1}{|c|}{ Innovation } & \multicolumn{1}{c|}{ Collaboration } \\
\hline Exclusionary dimension & 1 & 3 & 5 & 7 \\
\hline Transformative dimension & 2 & 4 & 6 & 8 \\
\hline
\end{tabular}

Table 2. Analysis matrix

\section{Results}

The CIFO have the same work methodology and thus, they operate in the same way which means that the results that we present in this article apply to all CIFO, although the quotes may come from one or two centres. There are two types of centres in the CIFO network in Catalonia: six CIFO (CIFO La Violeta, CIFO Sabadell, CIFO Santa Coloma de Gramenet, CIFO Salt, CIFO Tarragona, CIFO Lleida) and two CIFO who are also National Reference Centres (NRC) for Spain (CIFO L'Hospitalet de Llobregat, CIFO Sant Feliu de Llobregat). NRC have more autonomy, financial resources and staff than the rest of the CIFO, but also have additional responsibilities towards Spain.

CIFO function in the same way because they are part of the public administration and because they have the ISO 9001: 2008 certification. ISO 9001 is a standard that establishes the requirements for implementing a quality management system -'how an organization can meet the requirements of its customers and other stakeholders affected by its work' (ISO, 2015a, p. 2), and continuous improvement is its core philosophy. The CIFO are in process of adjusting to the ISO 9001:2015 version, which implies that they should open more to the society, because in a globalised context 'there are increased expectations from customers and other interested parties and, with more access to information, today's wider society has a stronger voice than ever before' (ISO, 2015b, p. 3). Innovation is a very important part in the CIFO work philosophy. As one of the interviewees put it:

Innovation, I think is good because you always get ahead of what the market demands and then the people we train in this way will always have more opportunity to find a job. (CF16ACUP04) 


\subsection{Autonomy}

\subsubsection{Exclusionary dimensions}

The first exclusionary dimension is related to the nature of the CIFO who are part of the public administration, and as such is ruled by the administrative law and the bureaucratic procedures. This fact causes disruptions in the normal functioning of the centres in terms of budgets approval (which affects the scheduling of the courses), provision of materials or improvements in infrastructure. Moreover, the public administration in Spain and in Catalonia suffered from budget cuts and political instability starting from the economic crisis in 2008 and this has also affected the CIFO.

The main barriers are those caused by the Generalitat itself. Because of the way it works. Because we depend on budgets [...]. Then, these budgets have to be approved and until they are approved, we cannot start courses. I would consider this to be the main problem [...] we have. (CF16ACUP07)

The second exclusionary dimension is related to the staff and the experts that work at the CIFO. The heads of the centres demand staff with the technical expertise in the respective professional fields of each CIFO, a strategic training of the staff oriented towards the activity carried by the CIFO, and more staff for the management of the centre. These issues affect less the two NRC, because they do have more staff.

[This centre] has been created with highly specialised staff and people. [...] and these people, became, in a certain moment, civil servants. And then, of course, CIFOs always had specialists inside. What happens is that of course, they are retiring and those of us who have been coming were not of that branch anymore. The civil service has been much stricter. [...] in the CIFO we have a lot of workshops. And a workshop is a very big responsibility, and the knowledge of the machinery. For people like us, with our profile, is difficult to reach a level of understanding and expertise that have these people, you know? (CF16ACUP03)

Moreover, the process of finding the experts is often challenging for the centres because of the scarcity of candidates who meet all the requirements established by the administrative procedure.

A person who works in the town hall or who works in the county council, or who works [...] who is a good professional, well, we cannot, because he already has a contract with the administration. [...] We can only take people who form the private company. (CF16ACUP06)

\subsubsection{Transformative dimensions}

One transformative dimension is the importance of the students' satisfaction for the CIFO. For this reason, the CIFO introduced a supplementary satisfaction survey during the first half of their courses, in addition to the compulsory survey at the end of the courses. The purpose of this intermediate survey is to detect anomalies or improvements that can be introduced in the specific course. Thus, these surveys are a tool continuous improvement in these centres. Through these surveys, the centres can address specific course issues such as mismatch between theory and practice, delay or lack of supplies or materials, and even poor performance of the experts (i.e. teaching staff) who, exceptionally, have been dismissed because of it.

[...] we saw that [with] this satisfaction survey at the end of the course we could not introduce elements of improvement if they were detected, if students had detected or if it was necessary on a forecast that we had made. [...] Then, it gives us much data in order to introduce those improvements that we detect, if there has been a minimum variation on the design that we have done and on that course. (CF16ACUP01)

A second transformative dimension is the selection of the experts, the term used for their teaching staff, because experts are an important asset for the centres and they can contribute to an up to date knowledge transfer from the private sector to the training in the CIFO. According to the administrative law the CIFO have no permanent teaching staff, so they initiate a new process for hiring each year. There are many requirements that the successful 
candidates have to meet in order to be selected and among these criteria, they are valued for their work experience in the private sector.

Of course, not having them implies that the development work that someone could do is not there, but it also means that everyone who enters new, their job in the future is at stake depending on how the course ends. According to the evaluation that we have in place, people put the enthusiasm and we can incorporate new technologies because we do not depend on training the expert so that $\mathrm{s} / \mathrm{he}$ can teach it after. (CF16ACUP02)

If they see that a professional certificate is already outdated, [...] it's a matter of making a proposal, make the corresponding reports and restructure the ' $\mathrm{X}$ ' certificate so that it can be adapted to the labor policies of [...] because they evolve a lot. (CF16ACUP05)

There are two possible ways of hiring staff: publishing a public offer, through the Employment Offices of the Catalan Employment Service, or looking up for experts (for example, using LinkedIn) or hiring a company that can provide this training. In both cases, the experts have to meet the criteria established by law. When they hire companies to do the training, CIFO can also hire materials or technology and this is another transformative dimension.

for example, in the CIFO that does multimedia they do it a lot. Because of course, being up to date with all the multimedia material would be impossible. Because what you use this year by the next it would be something else. Then they do it a lot. They do courses; they hire the company plus material. (CF16ACUP07)

Some of the interviewees expressed their hopes that the changes the CVET system in Catalonia is experiencing will be positive for the CIFO, because it may streamline administrative procedures, give CIFO more economic and autonomy, such as the possibility of offering services to the enterprises and charge money or equipment for that, or hiring more staff. If these changes will take place it would be another transformative dimension for the CIFO.

\subsection{Pedagogy}

\subsubsection{Exclusionary dimensions}

As an exclusionary dimension, some of the interviewees highlight that the low educational level of the students is a problem for the implementation of the curriculum. The courses that lead to professional certificates require entry levels that correspond to the level of formal education attained. Those who do not meet these formal education entry levels have the possibility to take an exam at the CIFO, which consists of language and mathematics tests. The problem with these tests is that the users do not receive the contents that will be tested, thus they cannot prepare it and many of them fail. However, for these people there is the option to take other courses that are more suited and present to these exams as many times as they want. There is also a problem with the foreign language competences, which is one of the obstacles to their participation in internship programmes such as Erasmus.

The problem in this country is that there are many people at the top, with a university education, few people in the middle, technical specialists, and many people without qualifications. It is very different from what happens in Germany. That the intermediate part is greatly enhanced, the part of low qualification is not enhanced so much. (CF16ACUP06)

One of the interviewees mentioned the '19th century' mentality, another exclusionary dimension, that approximately half of the students have in the audiovisual field; these students focus on acquiring diplomas and wait to be offered the perfect job.

Then there is another 50\% that continue in the 19th century, I would say. These people are waiting for an opportunity. [...] Of course, these people are the people who have many problems, because they do 
not understand where they are. It is not a matter of doing more Master degrees, or more courses, or that you show that you master many more programmes. You are the problem! The fact that you do not see is you who has to move and not wait for someone to arrive some day and make you the offer of your life. Because that offer will never come to you. (CF16ACUP02)

In some cases, these internships raise barriers both to the centres and the students. Interviewees explain that sometimes is hard to convince companies of the utility of receiving students in internships; as for the students, they do not receive an economic retribution for their work and, sometimes, it can imply changes of attitude, like learning or returning to the discipline that exists within a company, and this is an exclusionary dimension.

It is difficult for the company also, because to make the company see that it is an investment in the long run, that providing the company with trainees is not a waste of time, it is not that you have to be on top of this person and you have to "teach him" [...] but these are people who come to you with some competences, that come to you with a [working] methodology, perhaps not that of the company, loaded with vices throughout the years, but ours already come with a methodology of professional certificate. Of course, to the student you also have to explain that these are internships [...] that is not a work relationship. That these are not paid internships. And there are sometimes attitudinal issues that need to be modified. (CF16ACUP01)

A final exclusionary dimension is that the flexibility of the scheduling is not absolute. The equipment that some CIFO have is very expensive and thus it limits the possibility of change of the curriculum.

I have an equipment; therefore, I will have to maintain that equipment, but I have it there. I cannot transform a workshop and say: now I am going to do photovoltaic. Ok, now what do I do with all this? We have to think about the equipment that we have, the spaces we have. And, within that, we can move in the business world within our possibilities. (CF16ACUP06)

\subsubsection{Transformative dimensions}

The choice of the curriculum is mainly oriented towards the unemployed and it uses a set of tools in order to improve the employability of students. These tools, are a transformative dimension because it maximises the use of the resources, and it includes: data and tools of the Catalan Employment Service (Labour Market Observatory; Feina Activa, an internet website for job seeking; demands they receive from the companies; data from their Employment Offices, citizen demands), prospective studies and data of the labour market facilitated by the Spanish Ministry of Labour and Social Security, students, local roundtables with economic agents from the region where the CIFO can participate, InfoJobs portal.

Why [from the students]? Because they are qualified people that come from the sector. Because these are people who move; they have a clear idea about what is needed; who have to do a course and want to do this 3D stuff, or because they have a project. [...] Moreover, we try to follow the technological market, how is evolving. (CF16ACUP02)

CIFO have an advantage because their training is practical and sometimes they work with the latest technologies or equipment in the market and they create an enterprise environment to help students acquire working discipline.

People who are engineers, who have done engineering in the polytechnic or in any other university, and the equipment that we have here they do not have it polytechnic. Besides there have been people who had done engineering or Upper Grade Vocational Education and Training Cycles [the highest instance in the Spanish formal VET system], they come or request here the ... or maybe they say 'I just want to do the CATIA module, or NX, which is also in design'. Why? Because they did not study it at the [university]. (CF16ACUP05) 
Of course, the environment we have here is an that of an enterprise. That is, discipline in schedules, discipline in materials, discipline in the machines, trying to use them correctly, facilities are part of the same. (CF16ACUP07)

Another transformative dimension is the use of the project methodology. Students have to complete a project by the end of the course in order to complete their training, and this stimulates their creativity and problem solving skills, because they face real life situations. At one CIFO they have noticed that many students would not show up the last day of the course when they had to present the project. In order to solve the problem they have included in the courses sessions where they encourage students to make a public presentation to the rest of the class, where they have to explain their project, and they have also made the evaluation criteria more transparent to the students.

They will not explain to you how an illustration is made, no, you are going to illustrate a [...] book. This book you will illustrate it. Use the technique you want, but think about it, do a briefing, explain, and then you will explain it to all your colleagues and the people who have come to see the exhibition. You are going to take something that you have done [from the course]. Here we do not do written exams [...] here you make your product, you are evaluated, you take it and goodbye. (CF16ACUP02)

CIFO have some degree of flexibility and this is a transformative dimension because, on occasions, they are able to change the professional field.

Naturally, when the construction falls, it has a very sudden fall, logically, us where we turn to our programming [curriculum]? To sectors that emerge, sectors that need it. [...] We could not be forming more personnel in construction and public works because it would create more unemployment, and not to provide skills to people that the market required. [...] we strengthened more everything that is the area of sustainability and environmental management, with everything that was waste treatment, biocides treatment, harmful organisms ... why? Because even the norms, European directives required that all personnel working in biocides have to be accredited. Naturally, if they have to be accredited you have to give them training; you have to provide them with training. We are the only [CVET] centre that conducts courses on the management of harmful organisms or the application of biocides. (CF16ACUP01)

Regarding internships, a transformative dimension is that at one of the CIFO they encourage students to find their own arrangements according to their own interest and field that they would like to work. If they have a clear idea, about what they would like to work, they can be offered a list of companies and they are encouraged to contact and present themselves to these companies, and many students do that. However, this differs from one professional field to another. The innovation opportunity during the internship also depends on the professional field or type of enterprises.

students who have gave us feedback afterwards, tell us that yes, 'I go to that company and the method of work was still this and I explained that here at the CIFO I learned this way, and also the professional certificate includes it. [...] Yes, they liked it [...] There are companies that are more open, and that give student more autonomy. There are professional qualifications that also admit it more. Others do not. $[\ldots]$ Where there is a UNE norm or ISO norm, there you cannot ... It is not that you cannot innovate, it is just that the procedure is established in one way and you cannot introduce any type of modification. (CF16ACUP01)

\subsection{Innovation}

\subsubsection{Exclusionary dimensions}

The main obstacles for innovation in training at CIFO are the lack of equipment and of staff (less in the case of the NRC) and a lack of coordination between the providers of VET and CVET.

If you create it [innovation], it would be fantastic. It would be fantastic but we do not have the means for creation, we do not have enough methods or means or enough staff and we would have to do a huge 
research study here. And we do not have it. Because the staff is very scarce. The reality is that it is very scarce. (CF16ACUP01)

We work pure and core innovation aspects in our field. On training and innovation is more complicated. [...] one thing that is missing in this country is to clarify the map of resources. Who does what? Because in the end everyone does everything. And that means that nobody is doing anything. (CF16ACUP02)

\subsubsection{Transformative dimensions}

One transformative dimension is the detection of the innovation in the market, and introducing it in the specific professional trajectory by setting up experimental courses, in the curriculum they offer at the CIFO.

Experimental means that you experiment for two years. [...] it is not a [professional] certificate, obviously. It is our course. [We look] if the citizenship is interested in it and see the level of satisfaction of those students. We also look at the level of job insertion. (CF16ACUP03)

The use of technical sessions or professional visits are another transformative dimension because they constitute a transfer of innovation in a completely altruistic and free way, and is also a tool to detect innovation.

complementary activities, it means that companies come here to do an activity and that activity is based on the demonstration of their products so that we are at the latest in products and our students see the latest, what the company uses, the latest that is in the market, as well as that a company comes and exposes us in a concrete course a new method or a new methodology of work or application of its product. This is very important because the company, at the same time, diffuses its products and we, at the same time, know them. (CF16ACUP01)

Another transformative dimension at one of the CIFO is the commitment to introduce the technology as a pedagogical tool. On the one hand, they are planning to introduce online distance training (i.e. MOOC), so that people from all over Catalonia can enroll in their courses. On the other hand, they want to introduce technology for the online distance training, using computer software.

Training of mechanics, printers, welders, in any field. [...] We will have to create training interfaces and create simulators ... of course, a simulator also requires an interface and flexibility, and to be accessible to people and that this whole world is going to start opening. It is already open but it will open much more. The issue is [...] using the audiovisual technology that already exists: with an After Effects you can make The Lord of the Rings and you can do the disassemble of a machine marking with colors the different phases and how to make the disassemble and how they enter and how they stop entering. The tool is the same. (CF16ACUP02)

At another CIFO they are using webcam technology to create mixed teams with students from Quebec, for working on a project, for their transportation course.

We have an agreement with Quebec and our students will work with students of a Quebec institute to do a project. Yes, to do a joint project [...] we decided to do it then, via internet. With webcams, [...] try to relate two plus two or one plus one teams. [...] A final project [...] to set up a transport network, to carry merchandise. (CF16ACUP03)

Finally, some CIFO offer entrepreneurship or business creation courses. For these courses students are required to have already prepared a business idea or a project and during this course they get the help to advance or start with it. Moreover, at one of the CIFO specialised in audiovisual they have one transformative practice that consists in allowing students to borrow material and use the facilities for their own projects a year after they have finished a course.

Here, for example, to everyone who finishes a course, we leave them material for a year. We leave them cameras, tripods, the set... that is, they can come here to do a project and they can come without 
problem. As long as it does not affect the formative terrain [CIFO courses], we leave it to them to do their projects. (CF16ACUP02)

One interviewee considers that the local administration should get involved and create a network, at least at an informal level, where they can bring together the heads of the centres that offer VET and CVET and getting to know each other and what are they working, and establish the ground for collaboration between them. He gives the example of creating a platform for debate with the purpose of rationalizing investments and sharing resources between the VET and the CVET centres, which would be a transformative dimension.

At least know what the other does. [...] and at least we get together and at least look at rationalizing investments. Because this is expensive as hell. Because of course, in the end, we all end up buying the same thing [...] material, simply material [...] a $4 \mathrm{~K}$ camera can cost you $€ 150,000$, okay? [...] well it can be bought and start to rent or borrow, and keep it circulating. Things like that. Not to buy all the same and have all the same gaps. At least, set up a discussion forum and then, everyone can buy what they want. But, at least, let everyone know. Because, depending on the area we are all super equipped, we have material that is left over and then there are areas that no one enters. (CF16ACUP02)

\subsection{Collaboration}

\subsubsection{Exclusionary dimensions}

The main obstacles to the collaboration with enterprises are the legal obstacles. Due to the fact that CIFO are part of the public administration there are many limitations regarding their collaboration with private enterprises and other stakeholders. This situation could change when the new legislation regarding CVET will be effective. For example, the VET centres in Catalonia belong to the Education Department and have more autonomy than the CIFO centres who are under the Labour Department, as one of the directors says it:

We do not... if we were a center with economic or financial autonomy ... an IES [high school, in Spain] has financial autonomy or economic autonomy. We do not have any kind of economic or financial autonomy. We can not agree directly to the assignment or consideration of something, we can not do it directly.(CF16ACUP01)

\subsubsection{Transformative dimensions}

A transformative dimension is establishing a direct collaboration with enterprises and other stakeholders for training and innovation, which is a competence that only the CIFO who are also NRC have. One example is of one of these centres setting up an up-to-date training process with the material provided by one company and then this company could train its workers into this new process and the equipment remained at the CIFO. The CIFO that are also NRC also collaborate with professional associations, university experts and other stakeholders in the field (specialised centres, foundations), for the elaboration and revision of the professional certificates, or the impartation of training courses.

Now, for example, I want to set up this year a course that is devoted to the production of audiovisuals, which is also a lack, that people need to know how to make a production [...] and for this we want it to be taught by the Producers Association of Catalonia. We are going to contact them. They are people who can teach this course, well we look for resources, we hire and you set it up. (CF16ACUP02)

One of the interviewees was talking about a new model of CIFO that the Catalan Employment Service wants to implement, a CIFO more open that instills more confidence in civil, business and professional institutions so that there would be a little more correspondence and collaboration with the society. 


\section{Discussion}

The results show that many of the elements identified in the literature are implemented at the CIFO. Thus, we have seen how the ISO 9001 enhances innovation that improves the overall action of the public sector (CIFO) by improving performance, efficiency and meeting citizens' needs, pointed out by Mulgan and Albury. We have also seen how CIFO seek for emerging or innovative economic sectors mentioned by Guimarães (2012), in order to improve the employability of its students. Furthermore, as Sauer (2011) noted, CVET do not produce but it detects and establishes innovations, and as argued by Piercy (2010), the innovative training is supported by the Catalan government and by the EU. The innovative pedagogy developed at the CIFO do not respond exactly to what Jackson (2010) model, although VET can arguably develop transformative learning (Kilminster, 1997).

In the EU, innovation is important in formal or non-formal education from the lifelong learning approach. The innovative pedagogy developed at the CIFO corresponds more to the model promoted by the EU: placing the learner at the centre, using work-based learning, project methodology, working transversal competences, such as entrepreneurship, doing research and collaborating with the university and other stakeholders (European Commission 2001; European Council 2009), creating environments and simulating real work situations, organizing visits to companies and internships (Renta et al., 2017). Finally, it also incorporates technology in the classroom (Regmi 2015; Steffens, 2015).

Innovation at the CIFO has three main strands where we have identified many opportunities for the CIFO: methodological, pedagogical and technological. The methodological has to do with the actions derived from the ISO 9001 certification, which gives the centres the mission of continuous improvement and satisfying the needs of the people and enterprises in the territories they serve. Pedagogical innovation is related to the detection of the innovation and including it in the curriculum of the centre, organizing experimental training courses, using the project methodology, enhancing entrepreneurship, or introducing digital technologies in the classroom. Technological innovation is related to the use of the latest technologies and equipment in the market.

At the same time, we have also identified the most important challenges that CIFO face: legal limitations as a part of the public administration, bureaucratic procedures, budget cuts, staff shortage, low-educational level of part of the population, individual and company mentality, lack of collaboration between the CVET and the VET and reduced collaboration with enterprises.

\section{Conclusion}

The objective of this article was to fill a gap that we identified in the scientific literature, namely the relationship between innovation and CVET, as a part of lifelong learning. We have done so by examining a CVET programme for unemployed in Catalonia in two ways: interviewing the responsibles of the CIFO, who implement this CVET programme, and analysing the data using the transformative and exclusionary dimensions in order to highlight the opportunities and the challenges that these centres face in order to innovate.

One of the interviewees was saying that the innovative philosophy is one strength of the CIFO and its application is enhanced because all centres apply the same working methodology inspired by the ISO 9001 norms, which has continuous improvement, stakeholders' satisfaction and participation as key elements. Thus, the opportunities that CIFO have for innovation stem from this core philosophy which connects to their mission to tackle unemployment, by detecting or foreseeing the economical needs in their territory and offering relevant courses to match these needs. For this purpose, the relationship and collaboration of CIFO with the educational, social and economic actors in their respective territory is key and it should be enhanced further.

CIFO centres are part of the public administration and, as all interviewees point out, many of the challenges that the CIFO face could be overcome if the legal changes that are taking place in the CVET system will give them more autonomy, or at least bring them at the same level with the NRC. CIFO face challenges that are specific to the public administration. For example, CIFO depend on the yearly approval of the budgets of the Generalitat (the Catalan Government), they have suffered the cuts in the public sector or their collaboration with the private sector is very limited. The interviewee note that there is a will from the public administration to change this 
situation but the process is very slow and complex, and highly depended on the political arena. One of the interviewee mentioned one achievement in this aspect: the CIFO were not able to start their activity before the budget was approved and this was causing big delays and loss of potential for the centres; starting from 2016 the CIFO will start introducing biannual programming of their courses (note from the interview CF16ACUP08), therefore they will be able to maintain their activities and leverage their potential.

This study opens new venues for research in the area of VET, CVET and lifelong learning because of its implications in adjusting education and training to the requirements of the labor market and improving students' employability and helping them develop or design their personal projects and professional trajectory. It is also necessary to analyse the impact of these types of programmes and their transferability to other contexts.

\section{Declaration of Conflicting Interests}

The author declared no potential conflicts of interest with respect to the research, authorship, and/or publication of this article.

\section{Funding}

This study has received support from the Associació Catalana d'Universitats Públiques (ACUP) and Obra Social La Caixa 'RecerCaixa', grant 2014ACUP0077.

\section{References}

Albizu, E., Olazaran, M., Lavia, C., \& Otero, B. (2017). Making visible the role of vocational education and training in firm innovation: Evidence from Spanish SMEs. In press, 1-19. https://doi.org/10.1080/09654313.2017.1281231

Billon, M., Lera-Lopez, F., \& Marco, R. (2017). Patterns of Combined ICT Use and Innovation in the European Regions. Journal of Global Information Technology Management, 20(1), 28-42. https://doi.org/10.1080/1097198X.2017.1280302

Boeren, E., \& Holford, J. (2016). Vocationalism varies (a lot). A 12-country multivariate analysis of participation in formal adult learning. Adult Education Quarterly, 66(2), 120-142. https://doi.org/10.1177/0741713615624207

Brunet, I., \& Rodriguez-Soler, J. (2014). Vocational Training and innovation: Research on Innovation Transfer between VET Schools and Enterprises. Revista de Educación, 365, 177-201.

Cedefop (2014). Terminology of European education and training policy. Retrieved from: http://www.cedefop.europa.eu/en/publications-and-resources/publications/4117 (Last acces date: March, 2018).

Cedefop (2015). Stronger VET for better lives. Retrieved from: http://www.cedefop.europa.eu/en/publications-andresources/publications/3067 (Last access date: March, 2018).

Durrani, S. (2007). Learning by doing: Lifelong learning through innovations projects at DASS". Aslib Proceedings, 59(2), 187-200. https://doi.org/10.1108/00012530710736681

Ehlen, C.G.J.M., van der Klink, M.R., \& Boshuizen, H.P.A. (2016). Unravelling the social dynamics of an industry-school partnership: social capital as perspective for co-creation. Studies in Continuing Education, 38(1), 61-85. https://doi.org/10.1080/0158037X.2015.1030610

Elfert, M. (2015). UNESCO, the faure report, the delors report, and the political utopia of lifelong learning. European Journal of Education, 50(1), 88-100. https://doi.org/10.1111/ejed.12104

European Commission (2001). Making a European Area of Lifelong Learning a Reality. Retrieved from: http://eurlex.europa.eu/LexUriServ/LexUriServ.do?uri=COM:2001:0678:FIN:EN:PDF (consulted: March, 2018].

European Council (2009). Council conclusions of 12 May 2009 on a strategic framework for European cooperation in education and training ('ET 2020'). Retrieved from: http://eur-lex.europa.eu/legalcontent/EN/TXT/PDF/?uri=CELEX:52009XG0528(01)\&from=EN (Last access date: March, 2018). 
Faure, E., Herrera, F., Kaddoura, A.-R., Lopes, H., Petrovsky, A., Rahnema, M. et al. (1972). Learning to be. UNESCO: Paris.

Gómez, A., Puigvert, L., \& Flecha, R. (2011). Critical communicative methodology: Informing real social transformation through research. Qualitative Inquiry, 17(3), 235-245. https://doi.org/10.1177/1077800410397802

Gómez, J., Latorre, A., Sanchez, M., \& Flecha, R. (2006). Metodología comunicativa crítica. [Critical Communicative Methodology]. Barcelona: El Roure.

Guimarães, P. (2012). Critical links between recognition of prior learning, economic changes and social justice in Portugal. Journal of Adult and Continuing Education, 18(1), 61-76. https://doi.org/10.7227/JACE.18.1.6

ISO (2015a). Reaping the benefits of ISO 9001. Retrieved from:

https://www.iso.org/files/live/sites/isoorg/files/archive/pdf/en/reaping the benefits of iso 9001.pdf (Last access date: March, 2018).

ISO (2015b). Moving from ISO 9001:2008 to ISO 9001:2015. Retrieved from:

https://www.iso.org/files/live/sites/isoorg/files/archive/pdf/en/iso 9001 - moving from 2008 to 2015.pdf (Last access date: March, 2018).

Jackson, S. (2010). Innovations in lifelong learning: politics, power and pedagogic practices. In S. Jackson (ed.). Innovations in Lifelong Learning (p. 1-9). London: Routledge.

Janssens, J. (2002). Innovations in lifelong learning. Capitalising on ADAPT. Cedefop Panorama series, Nr. 25. Luxembourg: Office for Official Publications of the European Communities.

Kallison, J.M. (2017). The Effects of an Intensive Postsecondary Transition Program on College Readiness for Adult Learners. Adult Education Quarterly, 67(4), 302-321. https://doi.org/10.1177/0741713617725394

Kilminster, S. (1997). Vocational Education and Really Useful Knowledge. In 27th Annual SCUTREA conference. Retrieved from: http://www.leeds.ac.uk/educol/documents/000000252.htm (Last access date: March, 2018].

Lucio-Villegas, E. (2012). What's going on? An overview of adult education policies in Spain. Journal of Adult and Continuing Education, 18(1), 77-89. https://doi.org/10.7227/JACE.18.1.7

Lundvall, B.Å., \& Rasmussen, P. (2016). Challenges for adult skill formation in the globalising learning economya European perspective. International Journal of Lifelong Education, 35(4), 448-464.

https://doi.org/10.1080/02601370.2016.1203364

Piercy, G. (2010).Access and equity in Aotearoa/New Zealand: Increasing participation via policy and practice. In S. Jackson (ed.), Innovations in Lifelong Learning (pp. 167-187). London: Routledge.

Porto, I., Zabala-Iturriagagoitia, J.M., \& Larrakoetxea, U.A. (2017). Old wine in old bottles: The neglected role of vocational training centres in innovation. Vocations and Learning.

Pulido, C., Elboj, C., Campdepadrós, R., \& Cabré, J. (2014). Exclusionary and transformative dimensions: Communicative analysis enhancing solidarity among women to overcome gender violence. Qualitative Inquiry, 20(7), 889-894. https://doi.org/10.1177/1077800414537212

Regmi, K.D. (2015). Lifelong learning: Foundational models, underlying assumptions and critiques. International Review of Education, 61(2), 133-151. https://doi.org/10.1007/s11159-015-9480-2

Renta, A.I., Van den Bossche, P., Gijbels, D., \& Fandos, M. (2017). The Impact of Individual, Educational, and Workplace Factors on the Transfer of School-Based Learning into the Workplace. Vocations and Learning, 10(3), 275-306. https://doi.org/10.1007/s12186-016-9168-1

Sauer, J. (2011). Innovation and Learning - For a Future of Lifelong Learning. In: S. Jeschke, I. Isenhardt, F. Hees and S. Trantow (eds.), Enabling Innovation (p. 69-79). Berlin, Heidelberg: Springer. https://doi.org/10.1007/978-3-642-24503-9_8

Steffens, K. (2015). Competences, learning theories and MOOCs: Recent developments in lifelong learning. European Journal of Education, 50(1), 41-59. https://doi.org/10.1111/ejed.12102 
Stummann, C.B. (2014). Practice stories in natural resource management continuing professional education: Springboards for learning. Studies in Continuing Education, 36(3), 322-341. https://doi.org/10.1080/0158037X.2014.904786

Toner, P., \& Woolley, R. (2016). Perspectives and debates on Vocational Education and Training, skills and the prospects for innovation. Revista Española de Sociologia, 25(3), 319-342.

\section{Annex}

The interviews script

The script that was used for the interviews has been adapted for the CIFO and it originally came from the script that was used with the responsibles of the VET centres in Catalonia, for the research project "Formacio professional $i$ pimes: el repte de la innovacio a Catalunya", funded by RecerCaixa 2014. This is the original script, used in the research project.

\section{2.- GUIÓN ENTREVISTA DIRECTOR CENTRO FP}

Entrevista exploratoria a directores de centro o, en su defecto, responsables de las relaciones con las empresas. Se trata de recoger información sobre el funcionamiento del centro y especialmente sobre los distintos tipos de relaciones con las empresas (prácticas FCT, colocación/bolsa de trabajo de egresados, formación continua y ocupacional, otros servicios a las empresas). Seguir y aprovechar nuevas ramificaciones o puntos de interés que surjan en la entrevista.

\section{BLOQUE $1^{\circ}$.- DATOS BÁSICOS}

1) Datos básicos del centro.

1.1) Antigüedad y número de edificios.

1.2) Especialidades que oferta (especial énfasis en las especialidades industriales y grados superiores).

1.3) Número de alumnos desagregando por: número de adultos y de estudiantes en régimen de formación a distancia.

1.4) Restantes miembros de la plantilla (docente, administrativa y de servicios).

\section{BLOQUE $2^{\circ}$.- CURRÍCULUM INNOVADOR}

2) Entorno autonómico e innovación:

2.1) Valoración general del entorno regional y su incidencia en el desarrollo económico y tecnológico. ¿Qué aspectos del entorno regional favorecen o dificultan los procesos de innovación?

2.2) ¿Cree usted que se ha incrementado la necesidad de incluir competencias en innovación?¿por qué?

3) Según Decret 284/2011, d'1 de març, d'ordenació general de la formació professional inicial,

3.1) Qué medidas se han adoptado en relación a las tareas de investigación e innovación para el profesorado de su centro.

3.2) Cómo se valora la formación que en competencias en innovación reciben los alumnos. Cuál es su presencia dentro del curriculum académico.

3.3) Qué medidas se han adoptado para valorar la mejora continua del nivel de innovación impartido en su centro.

4) Qué resultado está dando, o es previsible de, el programa "InnovaFP" en relación a la transferencia de conocimientos en innovación entre: 
4.1) Su centro y las empresas con las que colaboran.

4.2) Su centro y otras entidades de su entorno.

5) En relación a la formación reglada:

5.1) ¿Cómo se planifica el curriculum académico en lo que respecta a la formación en capacidades de innovación?

5.2) Cuáles son los Módulos Profesionales -formativos- en los que se imparten.

5.3) En caso de la existencia de transversalidad innovadora, ¿cuáles son los criterios de valoración de los mismos?

5.4) La apuesta por la innovación se realiza, ¿en el primer o segundo ciclo o en ambos?

\section{BLOQUE $3^{\circ}$.- RELACIONES CENTROS-EMPRESAS.}

6) Formación para el Empleo (continua y ocupacional):

6.1) Qué tipo de formación (continua y/u ocupacional) son llevados a cabo en este centro.

6.2) Cuáles son los criterios para establecer la oferta formativa. Describa el papel de la conserjería o del departamento de Educación o de Empleo en esta cuestión.

6.3) Qué aporta este tipo de formación para su centro. Aspectos positivos y barreras que puedan existir a un mayor desarrollo de este tipo de actividad, tanto internas como externas a los centros de FP.

6.4) Qué tipo de formación de demanda imparten (sistema de bonificaciones, Fundación Tripartita) y cuál sería el tanto por ciento de la formación impartida en general. Qué opinión tienen sobre los cambios producidos en este tipo de formación.

6.5) Cómo se realiza la DAFO por el centro de FP? (según lo que se comentó en la entrevista con Ferran Castillo)

7) En relación a las prácticas de Formación en Centros de Trabajo (FCT) y a la relaciones entre tutores.

7.1) Las prácticas FCT, ¿denotan que existe un buen nivel de adaptación entre la oferta educativa en innovación y las necesidades de las empresas colaboradoras? Puntos positivos y puntos de mejora.

7.2) Qué mecanismos de consulta con las empresas existen a la hora de establecer la oferta educativa (educación inicial o reglada).

7.3) ¿Se realizan adaptaciones en el curriculum de la educación reglada en respuesta a las demandas de las empresas expresadas en las relaciones entre tutores? Concretamente, cuál es la capacidad de feedback con respecto a las competencias en innovación.

7.4) Qué tipo de relación se produce entre los tutores de las empresas y los tutores del centro a la hora de llevar a cabo las citadas prácticas. En su opinión, resulta efectiva. Aspectos positivos y negativos de ésta.

7.5) Los profesores del centro que llevan a cabo este tipo de actividad, suelen hacerlo a petición de las empresas. Puntos positivos y dificultades. Se debería realizar una mayor actividad a este respecto.

7.6) Las relaciones entre tutores del centro y de empresa suelen dar lugar a otros tipo de relaciones centro/empresa. Si es así indique algún ejemplo.

7.7) ¿El profesorado realiza estancias en empresas? Aspectos positivos y dificultades que existen al respecto

8) Participación de los trabajadores técnicos en las empresas: 
8.1) Qué tipo de relación existe entre los tutores de las empresas y los tutores del centro en dichas prácticas. En su opinión, resulta efectiva. Aspectos positivos y negativos de ésta.

8.2) Qué tipos de tareas realizan los trabajadores técnicos (especialmente de grado superior) en las empresas del entorno.

8.3) En su opinión qué aportación realizan/pueden realizar estos trabajadores -en comparación con otros empleados, por ej. los ingenieros- en los procesos de innovación en las empresas.

8.4) En su opinión, ¿qué impide/facilita que las propuestas innovadoras que parten de estos trabajadores se tengan en cuenta o se implementen finalmente?

8.5) Existe algún tipo de servicio de colocación de alumnos tras la realización de sus prácticas empresariales, como, por ejemplo, bolsas de trabajo.

8.6) Existen ejemplos de emprendeduría por parte de los alumnos una vez terminadas las prácticas/ formación?

9) Otros tipos de relaciones con la empresa:

9.1) ¿Existen otras formas de relación entre centros y empresas, por ejemplo: utilización de equipamiento, servicios técnicos? Alguna jornada, evento?

9.2) ¿Participan las empresas colaboradoras en el patronato o en alguna otra instancia del centro? ¿Cómo es esta relación?

9.3) ¿Existe algún tipo de inversión cruzada entre su centro y las empresas colaboradoras?

9.4) Se guarda registro acerca de la creación de empresas por parte de alumnos de FP.

9.5) ¿Existe algún apoyo a la hora de fomentar este tipo de servicios o proyectos de innovación? Funcionamiento, resultados.

9.6) ¿Se realizan otros servicios a las empresas: servicios técnicos, utilización del equipamiento del centro por parte de las empresas, proyectos de innovación? Aspectos positivos y dificultades.

9.7) ¿Podrían potenciarse más estos servicios en el futuro?

\section{BLOQUE $4^{\circ}$.- RELACIONES CENTROS-UNIVERSIDADES Y CENTROS TECNOLÓGICOS.}

10) Relaciones con la universidad y otros agentes:

10.1) Número de alumnos que acceden del grado medio al superior.

10.2) Número de alumnos que acceden del grado superior a la universidad.

10.3) Cuál es su opinión acerca de las posibilidades de la continuidad de los estudios desde el ciclo medio a la universidad. Puntos positivos y dificultades al respecto

10.4) ¿Tienen ustedes algún tipo de relaciones con la universidad? En su opinión, cuál sería el nivel de colaboración adecuada.

10.5) ¿Tienen ustedes algún tipo de relación con otros con agentes técnicos, como los centros tecnológicos? ¿Qué potencialidades y barreras existen al respecto?

Intangible Capital, 2018 (www.intangiblecapital.org)

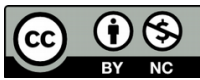

Article's contents are provided on an Attribution-Non Commercial 4.0 Creative commons International License. Readers are allowed to copy, distribute and communicate article's contents, provided the author's and Intangible Capital's names are included. It must not be used for commercial purposes. To see the complete license contents, please visit https://creativecommons.org/licenses/by-nc/4.0/. 